\title{
STRATEGI MENGHADAPI BENCANA TANAH LONGSOR DI DESA SNEPO KECAMATAN SLAHUNG KABUPATEN PONOROGO
}

\author{
Gede Sarya $^{1^{*}}$, Tri Pramesti ${ }^{2}$, Billy Arrowrichta $^{3}$, Hiasintus Bertus Watu $^{4}$ \\ 1,2,3,4 Universitas 17 Agustus 1945, Л. Semolowaru 45, Surabaya \\ *Penulis korespondensi; email: gedesarya@untag-sby.ac.id, tripramesti@untag-sby.ac.id
}

\begin{abstract}
Abstrak: Hampir setiap tahun saat musim hujan tiba, bencana tanah longsor menghantui penduduk Desa Snepo Kecamatan Slahung kabupaten Ponorogo. Tanah longsor terbesar terjadi pada tahun 2017 silam ketika puluhan rumah rusak berat dan puluhan ekor sapi menjadi korban serta terputusnya akses jalan yang menghubungkan antara dusun satu dengan dusun dan desa lain. Dari survei yang dilakukan, bencana akan semakin mengancam karena adanya perubahan penggunaan lahan yang semula berupa hutan rakyat berubah menjadi lahan pertanian. Pemanfaatan lahan sebagai lahan pertanian memanfaatkan lereng yang relatif curam, sehingga erosi akan sering terjadi dalam bentuk erosi alur dan gerakan massa tanah (longsor). Erosi pada tingkat lanjut ini menyebabkan dampak yang besar bagi kerusakan lingkungan, misalnya banjir, tanah longsor, dan daerah rawan longsor. Pada sisi yg lain pengetahuan masyarakat tentang pelestarian hutan dan sumberdaya air masih rendah. Permasalahan yang dihadapi warga Desa Snepo yang berkaitan dengan ancaman bencana yaitu: (1) Penduduk desa snepo, terutama yang bermukim di daerah rawan bencana selalu merasa was-was dan takut terhadap datangnya bahaya tanah longsor. (2) Pengetahuan masyarakat tentang pelestarian hutan sebagai daerah tangkapan air dan mitigasi bencana masih sangat rendah. Upaya untuk mengantisipasi dampak dari bencana tanah longsor dan banjir bandang adalah membuatkan peta lokasi rawan longsor dan peta aliran air hujan yang dijadikan pedoman masyarakat yang akan membangun rumah. Manfaat yang diharapkan adalah dapat membantu menciptakan ketentraman, kenyamanan dalam kehidupan masyarakat Desa Snepo kecamatan Slahung kabupaten Ponorogo.
\end{abstract}

Kata kunci: Peta; bencana; tanah longsor.

\begin{abstract}
Almost every year when the rainy season arrives, a landslide disaster haunts the residents of Snepo Village, Slahung District, Ponorogo Regency. The biggest landslide occurred in 2017 when dozens of houses were severely damaged and dozens of cows were victims as well as the cut off of the access road connecting one hamlet with another hamlet and village. From the survey conducted, the disaster will be increasingly threatening because of changes in land use which was originally in the form of community forests turned into agricultural land. The change of land function into agricultural land by utilizing relatively steep slopes will cause erosion, so that disasters will often occur in the form of channel erosion and soil mass movements (landslides). Erosion at this advanced level has a great impact on environmental damage, for example floods, landslides and landslide prone areas. On the other hand, community knowledge about forest conservation and water resources is still low. The problems faced by Snepo villagers relating to the threat of disaster are: (1) Snepo villagers, especially those who live in disaster prone areas, always feel alarmed and afraid of landslides. (2) Community knowledge about forest conservation as a water catchment area and disaster mitigation is still very low. Efforts to anticipate the effects of landslides and flash floods are to create maps of landslide-prone locations and maps of rainwater flow that are used as guidelines for the community that will build houses. The expected benefit is that it can help create peace, comfort in the life of Snepo village community, Slahung district, Ponorogo regency.
\end{abstract}

Keywords: Map; disaster; landslide.

\section{PENDAHULUAN}

Desa Snepo adalah desa yang termasuk bagian dari 22 desa di Kecamatan SlahungKabupaten Ponorogo. Sesuai dengan namanya "slahung" berasal dari bahasa Jawa "slah gunung", artinya berada di sela-sela gunung. Jarak kantor Desa Snepo ke ibukota kecamatan sejauh $\pm 12 \mathrm{~km}$ dan ke ibukota kabupaten sejauh $\pm 34 \mathrm{~km}$. Topografi desa tersebut $>66,65 \%$ nya berupa perbukitan/pegunungan dengan kemiringan antara $30{ }^{\circ} \mathrm{s} / \mathrm{d} 85^{\circ}$. Desa Snepo terletak di ketinggian 755 
mdpl s/d 900 mdpl, secara administrasi Desa Snepo terdiri dari 4 (empat) dusun yaitu Dusun Krajan, Dusun Kowang, Dusun Genuk dan Dusun Salak.

Kondisi hidrologi seperti kondisi air tanah tidak mengandung kadar garam yang tinggi sehingga memberi kemudahan pemilihan tanaman tropis yang variatif. Kondisi iklim, rata-rata curah hujannya mencapai $2000 \mathrm{~mm}$ pertahun, suhu berkisar antara $28^{\circ} \mathrm{C}-30^{\circ} \mathrm{C}$ dengan iklim tropis. Hampir setiap tahun saat musim hujan tiba, bencana tanah longsor terus menghantui penduduk kedua desa tersebut. Tanah longsor terakhir terjadi bulan Pebruarai - Maret 2018, satu rumah rusak berat, 20 rumah terancam longsoran tanah dan sedikitnya 141 jiwa harus mengungsi serta terputusnya akses jalan yang menghubungkan dengan dukuh dan desa lain. Belum lagi longsoranlongsoran kecil yang sering terjadi saat musim hujan di semua dusun.

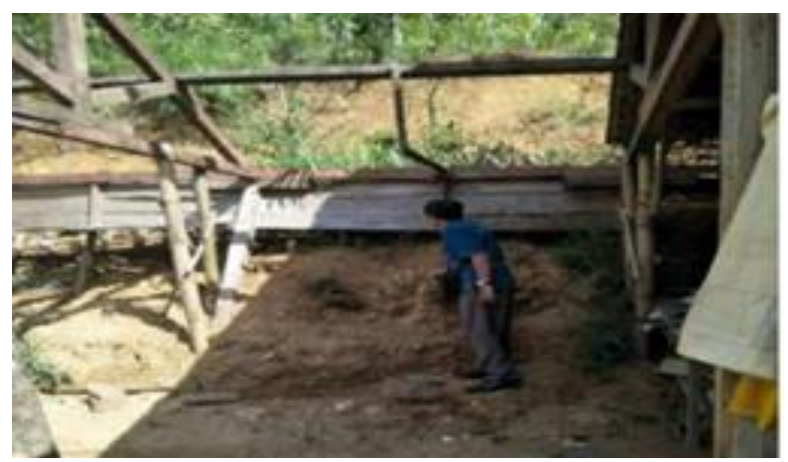

(a)

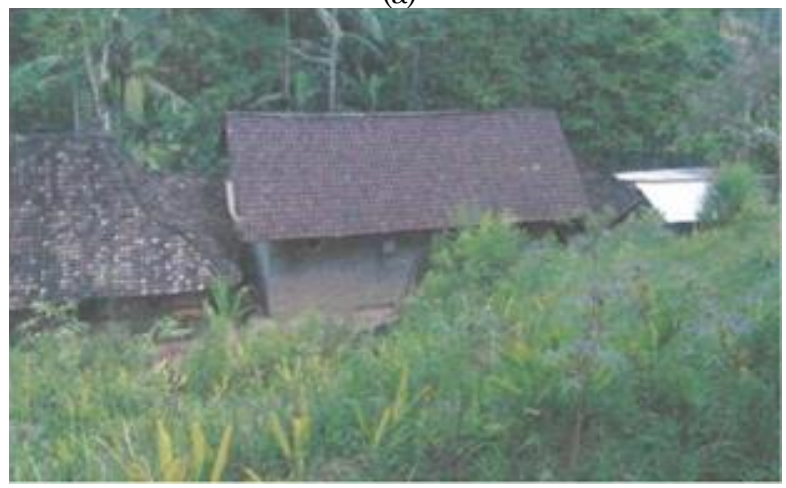

(b)

Gambar 1. (a) Rumah rusak berat akibat longsoran di Dusun Gembes (b) rumah yang terancam longsoran di Dusun Genuk

Bencana akan semakin mengancam karena adanya perubahan penggunaan lahan yang semula berupa hutan rakyat berubah menjadi lahan pertanian. Pemanfaatan lahan sebagai lahan pertanian memanfaatkan lereng yang relatif curam, sehingga erosi akan sering terjadi dalam bentuk erosi alur dan gerakan massa tanah (retakan) disamping itu sistem drainase permukaan yang kurang baik sehingga seluruh air baik air hujan maupun air limbah rumah tangga menjenuhi lereng sehingga mempercepat berkembangnya longsor.

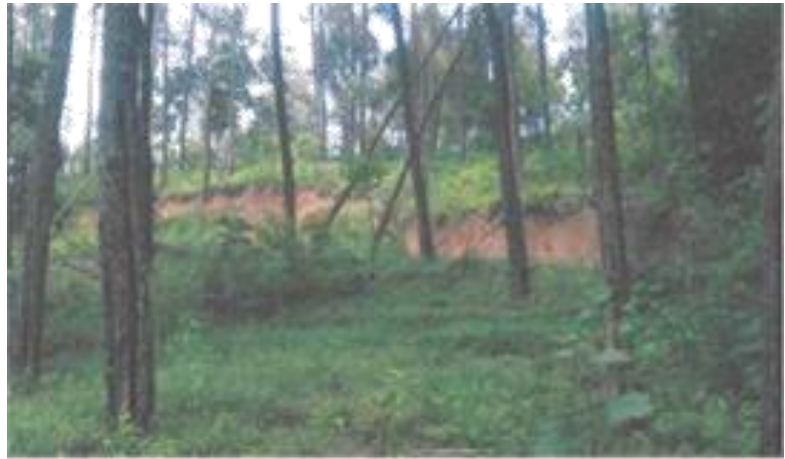

(a)

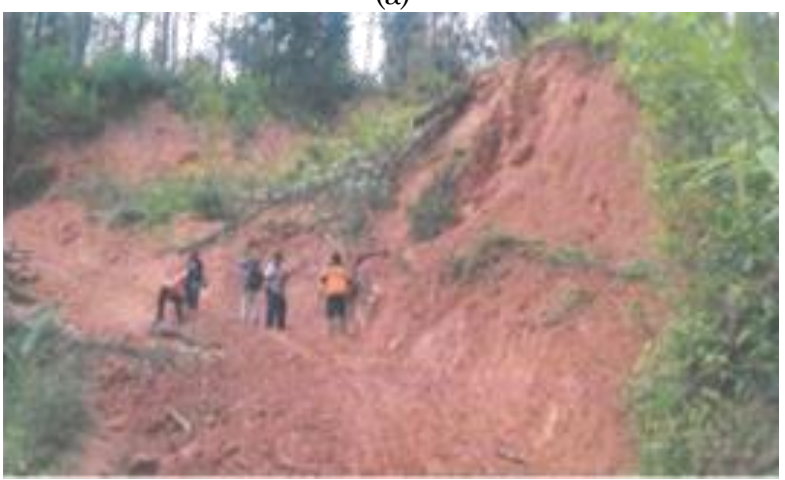

(b)

Gambar 2. (a) Retak pada bagian atas, turun $50-125 \mathrm{~cm}$ panjang $55 \mathrm{~m}$, (b) Longsor di Lingkungan Joso dan tidak mengarah ke pemukiman warga

Secara umum faktor penyebab terjadinya gerakan tanah di lokasi kegiatan PKM antara lain adalah:

- Kemiringan lereng yang terjal mengakibatkan tanah mudah bergerak

- Struktur geologi berupa patahan turun dilokasi gerakan tanah

- Jenis batuan berupa lava/breksi yang bersisipan batu lempung dan batu pasir

- Sifat tanah pelapukan bersifat poros/sarang, kurang kompak, jenuh air

- Sistem drainase permukaan yang kurang baik sehingga seluruh air baik air hujan maupun air limbah rumah tangga menjenuhi lereng sehingga mempercepat berkembangnya longsor

- Curah hujan yang tinggi dan berdurasi lama yang turun sebelum dan saat terjadinya gerakan tanah memicu terjadinya gerakan tanah.

\section{PERMASALAHAN YANG HARUS DITANGANI}

Dari analisis situasi tersebut di atas dan informasi yang diperoleh dari kepala desa, kepala dusun dan tokoh masyarakat, permasalahan yang dialami oleh warga Desa Snepo yaitu:

1. Penduduk selalu merasa was-was terhadap datangnya bahaya tanah longsor saat musim hujan.

2. Pengetahuan masyarakat tentang tata guna lahan serta mitigasi bencana masih sangat rendah. 
3. Sistem drainase permukaan yang kurang baik sehingga seluruh air, baik air hujan maupun air limbah rumah tangga menjenuhi lereng sehingga mempercepat berkembangnya longsor.

4. Belum adanya lembaga ditingkat desa yang menangani masalah kebencanaan.

\section{METODE PELAKSANAAN}

Berdasarkan permasalahan yang dihadapi oleh masyarakat Desa Snepo dalam menghadapi ancaman bahaya tanah longsor tersebut, maka metode yang dilakukan untuk memecahkan berbagai permasalahan tersebut adalah sebagai berikut:

1. Memberikan pemahaman pada penduduk Desa Snepo tentang daerah/lokasi rawan longsor dan aliran air

2. Memberikan penyuluhan tentang:

a. Bagaimana menghadapi bahaya tanah longsor

b. Mitigasi bencana

3. Melakukan pemetaan pada areal terdampak bencana tanah longsor

4. Melakukan pemetaan daerah aliran air

5. Edukasi kepada masyarakat tentang kedaruratan bencana

\section{HASIL DAN PEMBAHASAN}

\section{Survey}

Kegiatan awal yang dilakukan oleh tim Pengabdian Masyarakat adalah melakukan survei, bermitra dengan BPBD Kabupaten Ponorogo. Dari survei diperoleh informasi tentang keadaan Desa Snepo beserta struktur tanahnya. Dari hasil survei tersebut diperoleh gambaran sebagai berikut;

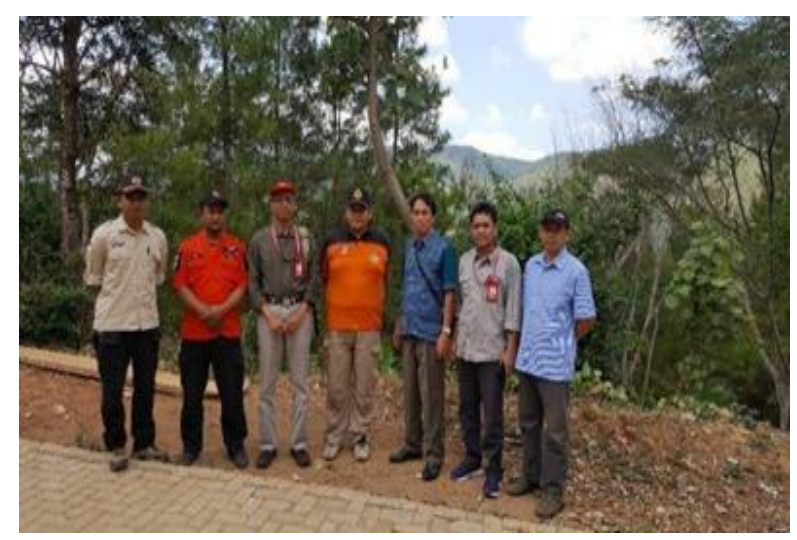

Gambar 3. Tim survey di lokasi PKM (Desa Snepo), turut serta tim dari BPBD Kabupaten Ponorogo

Data yang berhasil dihimpun oleh tim survey dan data dari BPBD Kabupaten Ponorogo berkaitan dengan gerakan tanah di Desa Snepo Kecamatan Slahung, Kabupaten Ponorogo, antara lain di: a. RT 05/RW 2 Lingkungan Klandri, Dusun Genuk, Desa Snepo, Kecamatan Slahung, Kabupaten Ponorogo, Provinsi Jawa Timur. Secara geografis terletak pada koordinat $08^{\circ} 04^{\prime} 23.6 \mathrm{LS}$ dan $111^{\circ} 23$ '42.7 "BT longsor dilokasi ini terjadi pada tanggal 3 Februari 2018, namun gerakan tanah tipe lambat disekitar lokasi ini sudah sering terjadi. Serta di lingkungan Mbolo, Dusun Kowang, Desa Snepo, Kecamatan Slahung. Secara geografis lokasi longsor terletak pada koordinat $08^{\circ} 04^{\prime} 38.1$ 'LS dan $111^{\circ} 22$ 55.22 "BT. Bencana longsor ini terjadi pada hari Jum'at, tanggal 10 Maret 2018, namun pergerakan lambat ini sudah terjadi sebelumnya sekitar tahun 2016. Serta di lingkungan Prapatan, Dusun Kowang, Desa Snepo, Kecamatan Slahung. Secara geografis lokasi longsor terletak pada koordinat $08^{\circ} 03^{\prime} 34.9^{\prime \prime} \mathrm{LS}$ dan $111^{\circ} 22^{\prime} 26.3^{\prime \prime}$ BT. Longsor terjadi pada tanggal 12 Februari 2018.

Dampak dari pergerakan tanah di desa tersebut terangkum sebagai berikut:

- Warga dilingkungan Klandri, Dusun Genuk khawatir terjadi longsoran yang lebih besar dan menimpa pemukiman di bawahnya

- Lingkungan Mbolo, Dusun Kowang; warga Mbolo khawatir terjadi longsoran besar ke pemukiman dan beberapa rumah retak

- Lingkungan Parapatan, Dusun Kowang; 7 (tujuh) rumah terancam longsor dan sudah mengungsi ketempat yang aman.

- Lingkungan Joso, Dusun Tugunongko; warga disekitar longsoran khawatir terjadi longsoran yang mengarah kepemukiman.

- Lingkungan Kalimati, Dusun Tugunongko; 2 (dua) rumah terancam longsor (rumah Pak Sumardi dan Mbah Jarno)

- 141 warga di Desa Slahung mengungsi ke tempat yang lebih aman karena khawatir terjadi longsoran.

- Pembangunan rumah warga belum mempertimbangkan faktor bahaya tanah longsor.

- Masih banyak warga membangun rumah di daerah lembah (palung).
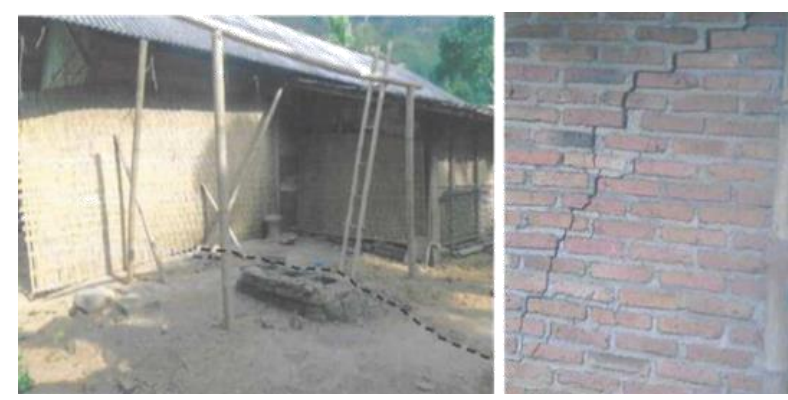

Gambar 4. (a) retakan yang merusak pemukiman dan memotong rumah, (b) retakan pada pemukiman di lingkungan Mbolo akibat gerakan tanah lambat. 


\section{Kegiatan Penyuluhan}

Salah satu strategi untuk mengantisipasi bahaya tanah longsong adalah penyuluhan kepada masyarakat terdampak. Penyluhan ini juga bagian dari edukasi kepada masyarakat tentang kedaruratan bencana

Kegiatan penyuluhan dibagi menjadi beberapa tahap yaitu:

1. Penyuluhan mitigasi bencana. Dari penyuluhan ini masyarakat menjadi tahu lokasi rawan longsor dan sigap bila ada bencana.

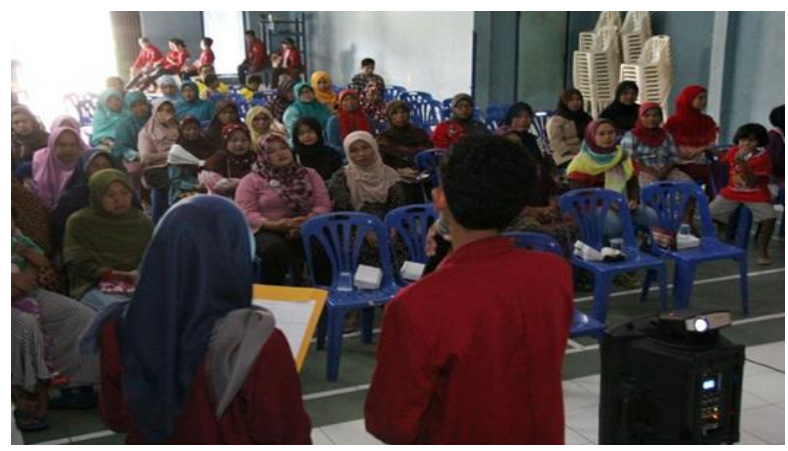

2. Penyuluhan pelestarian hutan. Penyuluhan ini memberikan pemahaman kepada masyarakat tentang fungsi hutan.

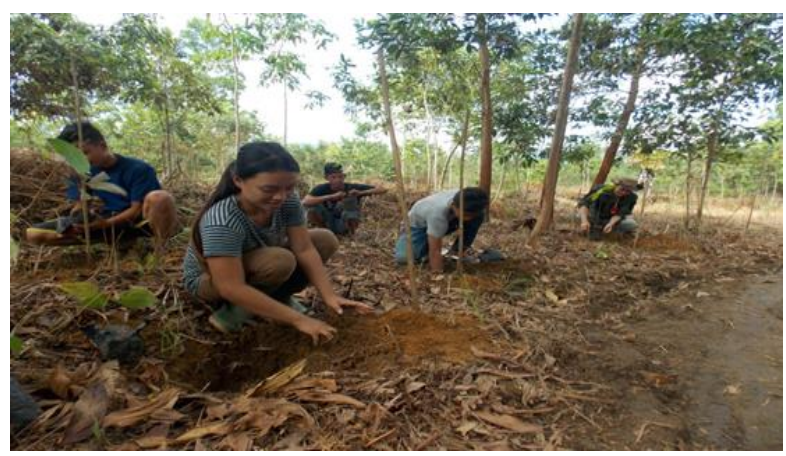

\section{Menyusun Peta}

Pembuatan peta daerah rawan longsor untuk Desa Snepo dan Pembuatan peta aliran air hujan untuk Desa Snepo.

\section{SIMPULAN}

Program Pengabdian kepada Masyarakat (PKM), ini diusulkan oleh Lembaga Penelitian dan Pengabdian kepada Masyarakat (LPPM) Universitas 17 Agustus 1945 (UNTAG) Surabaya yang memiliki visi dan misi sejalan dengan Program DIKTI tentang Pengabdian Masyarakat dan berkomitmen untuk ikut serta dalam menanggulangi kemiskinan dan menyejahterakan masyarakat melalui kegiatan penelitian dan pengabdian kepada masyarakat di bidang perekonomian, pertanian, penerapan teknologi dan pemberdayaan masyarakat.

Untuk menyelesaikan permasalahan yang dihadapi oleh mitra adalah dengan melakukan penyuluhan menysun peta rawan longsor, peta aliran air hujan, melakukan mitigasi bencana, mengadakan edukasi tentang bencana tanah longsor.

\section{UCAPAN TERIMA KASIH}

Ucapan terimakasih atas terlaksananya kegiatan pengabdian ini disampaikan kepada:

1. Universitas 17 Agustus 1945 Surabaya melalui LPPM yang telah memberikan bantuan hibah pengabdian.

2. Badan Penanggulan Bencana Daerah (BPBD) Jawa Timur yang mendukung kegiatan ini dalam bentuk memberikan informasi daerah terdampak Bencana di Kabupaten Ponorogo.

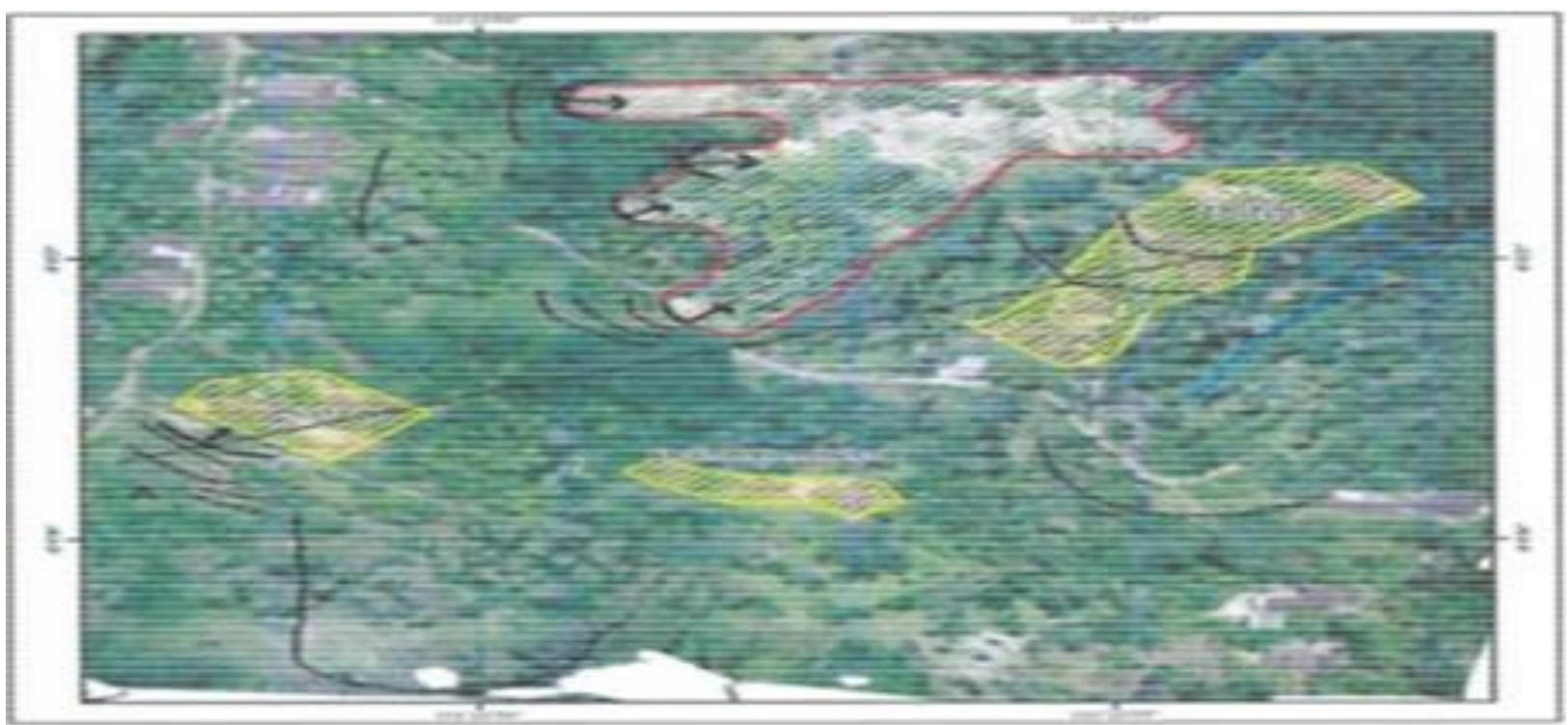

Gambar 5. Peta situasi gerakan tanah di desa Snepo. Hasil pemetaan menggunakan UAV dan pengamatan lapangan 
3. Kepala Desa Snepo Kecamatan Slahung Ponorogo yang telah memberikan persetujuan dan motivasi dalam terlaksananya kegiatan ini

4. Warga Desa Snepo Kecamatan Slahung Kabupaten Ponorogo yang telah mendukung dan terlibat di dalam kegiatan ini srehingga pengabdian masyarakat yang kami lakukan terlaksana dengan baik.

5. Berbagai pihak yang membantu pelaksanaan kegiatan Pengabdian Masyarakat ini.

\section{DAFTAR PUSTAKA}

Ayala, Kenneth J., 1991, The 8051 Microcontroller Architecture, Programming, and Application, Western Publishing Company, New York-LA.

Hary Christady Hardiyatmo, 1992, Mekanika Tanah I, Gramedia Pustaka Utama, Jakarta. Joseph E. Bowles, 1991, Sifat-Sifat Fisis dan Geoteknis Tanah, Erlangga, Jakarata. 